\title{
Effectiveness of banana leaves extract (Musa paradisiaca L.) for wound healing
}

\section{Efektifitas gel ekstrak daun pisang (Musa paradisiaca L.) untuk penyembuhan luka}

\author{
Dimas Ariandi Candra Putra, Heni Lutfiyati* ${ }^{*}$ Prasojo Pribadi \\ Program Studi DIII Farmasi \\ Fakultas Ilmu Kesehatan, Universitas Muhammadiyah Magelang \\ Jl. Mayjend Bambang Soegeng Mertoyudan Km 5, Magelang
}

\section{ABSTRAK}

Daun pisang (Musa paradisiaca,L.) belum banyak dimanfaatkan dalam pengobatan Tujuan penelitian ini adalah untuk menguji aktivitas penyembuhan luka dari ekstrak daun pisang (Musa paradiasiaca L.) yang dibuat sediaan gel dan menentukan konsentrasi paling efektif untuk penyembuhan luka. Target penelitiannya adalah memberikan alternatif pengobatan luka secara alami. Metode penelitian yang digunakan adalah penelitian eksperimental. Prosedur penelitian dimulai dengan identifikasi daun pisang, pembuatan ekstrak daun pisang, pembuatan gel ekstrak daun pisang dengan konsentrasi 1\%,5\%,10\% dan pengujian ke hewan uji yang dilukai. Hewan uji dikelompokkan menjadi 5 kelompok yaitu kelompok kontrol negatif (basis gel), kontrol positif (bioplacenton), dan 3 kelompok perlakuan. Pengukuran diameter luka dilakukan pada hari ke-1 sampai dengan hari ke-7. Hasil pengamatan diuji dengan menggunakan Anova dan Post Hoc Tukey HSD. Hasil uji ANOVA menunjukkan terdapat perbedaan signifikan rerata presentase penyembuhan luka antar semua kelompok perlakuan. Hasil Post Hoc Tukey HSD pada taraf kepercayaan 95\% menunjukkan perbedaan bermakna pada kelompok kontrol negatif bila dibandingkan dengan kelompok kontrol positif dan kelompok perlakuan gel 5\% dan 10\%. Hal ini menunjukkan bahwa kontrol positif, gel 5\% dan $10 \%$ mempunyai efek penyembuhan luka. Kelompok kontrol positif bila dibandingkan dengan kelompok perlakuan gel 5\% dan 10\% menunjukkan perbedaan bermakna yang nilai rerata persentase penyembuhan luka kontrol positif lebih tinggi dibandingkan kelompok perlakuan. Hal ini berarti perbedaan yang dimaksudkan bahwa kontrol positif memiliki aktivitas yang lebih baik. Sedangkan kelompok gel 5\% bila dibandingkan dengan kelompok gel 10\% tidak ada perbedaan yang bermakna hal ini berarti kelompok gel 5\% dengan 10\% mempunyai efektifitas penyembuhan luka yang sebanding.

Kata kunci : gel, daun pisang, luka 


\begin{abstract}
Banana leaves (Musa Paradisiaca, L.) has not been widely used in the treatment purpose of this study was to examine the wound healing activity of the gel of banana leaves (Musa paradiasiaca L.) and determine the most effective concentration for wound healing.Target research is to provide natural wound treatment alternatives. The method used is eksperimental.Prosedur research study began with the identification of a banana leaf, banana leaf extraction, formulation of banana leaf extract gel with a concentration of $1 \%, 5 \%, 10 \%$ and testing to the test animals were harmed .Animal test are grouped into 5 groups the negative control group (base gel), a positive control (bioplacenton), and 3 groups treatment. Measuring of diameter wound on day-1 through day 7. The observation was tested by using ANOVA and Post Hoc Tukey HSD. ANOVA test results showed a significant difference between the mean percentage of wound healing all groups Treatment.The result of Post hoc Tukey HSD at the 95\% confidence level showed significant differences in the negative control group when compared to the positive control group and the treatment group gel 5\% and 10\%.It indicates that the positive control, gel 5\% and 10\% have a wound healing effect. Positive control group compared with the group treated gel 5\% and 10\% showed significant differences that the average value of the percentage of wound healing is higher than the positive control treatment group. It means the difference meant that the positive control has better activity. While the group gel 5\% when compared with the $10 \%$ gel group no significant difference in this case means the group gel $5 \%$ with $10 \%$ having a comparable effectiveness of wound healing.
\end{abstract}

Keywords : gel, banana leaves, wound healing

\title{
PENDAHULUAN
}

Luka merupakan masalah yang sering dijumpai didalam kehidupan di masyarakat sejak lama. Luka dapat terjadi pada siapapun saja. Semua orang tersebut pernah mengalami beberapa jenis luka entah itu luka kecil yang dapat disembuhkan dengan cepat maupun mengalami luka kronik yang sulit disembuhkan dan menimbulkan nyeri hebat (Advanced Medical Technology Association, 2006).

Salah satu tanaman yang berkhasiat menyembuhkan luka adalah pisang (Musa paradisiaca L.). Efek farmakologi dari tanaman pisang adalah anti ulcer, penyembuh luka, antioksidan, penangkal untuk gigitan ular, hipoglikemik, aterogenik, dan augmentasi otot rangka (Swathi, 2011). Menurut Karuppiah (2013) daun pisang mempunyai aktivitas antibakteri terhadap infeksi nosokomial. Sahaa (2013) menemukan bahwa pada daun pisang terdapat berbagai jenis senyawa aktif fitokimia termasuk alkaloid, flavonoid, steroid, glikosida, dan saponin.

Weremfo (2011), menyatakan bahwa jus batang pisang terbukti memiliki efek hemostatik. Salep yang mengandung ekstrak jus batang $10 \%$ memiliki aktivitas penyembuhan luka paling efektif. Ekstrak kental tanaman pisang kepok kuning baik itu akar, bonggol, pelepah, daun, jantung pisang maupun buahnya memiliki potensi sebagai antibakteri terhadap bakteri uji Staphylococcus aureus dan Escherichia coli dan ekstrak kental bonggol pisang memiliki diameter daerah hambat bakteri tertinggi terhadap S. aureus yang bersifat radikal dan E. coli yang bersifat radikal (Ningsih, 2013).

Walaupun tanaman pisang mudah tumbuh dan banyak ditemui tetapi penggunaan daun pisang hanya sebagai sebagai pembungkus makanan dan belum dimanfaatkan untuk pengobatan. Penggunaan ekstrak daun pisang untuk menyembuhkan luka dapat dipermudah dengan membuat dalam bentuk sediaan gel. Gel penggunaannya lebih disukai karena memiliki kandungan air yang bersifat mendinginkan, menyejukkan, melembabkan, mudah penggunaannya, mudah berpenetrasi pada kulit, sehingga memberikan efek penyembuhan yang lebih cepat sesuai basis yang digunakan (Ansel, 2005).

Berdasarkan hal tersebut mendorong peneliti untuk mengadakan penelitian mengenai ekstrak daun pisang yang dibuat dalam sediaan gel untuk penyembuhan luka dan menentukan konsentrasi efektif ekstrak daun pisang dalam menyembuhkan luka. Diharapkan gel ekstrak daun pisang yang dihasilkan mampu mempercepat penyembuhan luka sehingga dapat digunakan sebagai pengobatan alami yang selanjutnya dikembangkan menjadi sediaan fitofarmaka serta sebagai acuan untuk penelitian selanjutnya dalam menunjang perkembangan ilmu pengetahuan. 
Tujuan dari penelitian ini adalah untuk menguji aktivitas penyembuhan luka dari gel ekstrak daun pisang dan menentukan konsentrasi ekstrak daun pisang dalam gel yang efektif dalam menyembuhkan luka.

\section{METODE PENELITIAN}

\section{Alat dan Bahan}

Alat -alat yang digunakan adalah sarung tangan, alat-alat gelas, timbangan hewan, neraca analitik, rotary evaporator, batang pengaduk, cawan porselin, pot plastik, sudip, spatula, water bath, aluminium foil, mikro pipet, kertas saring, mortir, stemper, blender, gunting, mata pisau (scalpel), kamera digital, cottonbud, masker, kasa, plester dan kandang tikus. Bahan-bahan yang digunakan adalah alkohol 70\%, CMC-Na, gliserin, propilenglikol, Bioplacenton ${ }^{\circledR}$, ketamin injeksi, tikus putih jantan galur Wistar umur 3 bulan berat badan 200-300 gram, daun pisang.

\section{Jalannya Penelitian}

\section{Identifikasi tanaman pisang}

Identifikasi tanaman pisang dilakukan di laboratorium Biologi Farmasi Universitas Ahmad

Dahlan Yogyakarta, yaitu mencocokkan ciri-ciri morfologinya dengan pustaka.

\section{Penyiapan bahan}

Daun pisang dicuci bersih, dipotong-potong dan dijemur terlindung sinar matahari langsung selama 6-7 hari. Daun yang telah kering dioven untuk menghilangkan sisa kadar air dalam suhu $45^{\circ} \mathrm{C}$ selama 3 jam. Daun kering dibuat serbuk dengan diblender dan diayak.

\section{Ekstraksi daun pisang}

Serbuk daun pisang sebanyak $1 \mathrm{Kg}$ dimaserasi dengan etanol $70 \%$ sebanyak $2000 \mathrm{ml}$ dalam bejana yang ditutup aluminium foil dan didiamkan selama 3-4 hari dengan pengadukan setiap harinya. Kemudian maseratnya disaring menggunakan corong Buchner, dievaporasi dan selanjutnya diuapkan diatas water bath. Ampas dari maserasi pertama kemudian diremaserasi kembali sebanyak dua kali.

\section{Pembuatan gel ekstrak daun pisang}

Formulasi gel ekstrak daun pisang dengan konsentrasi 1\%, 5\% dan $10 \%$

Tabel I. Formulasi gel ekstrak daun pisang

\begin{tabular}{cccc}
\hline Bahan & Gel 1\% & Gel 5\% & Gel 10\% \\
\hline Ekstrak & $0,25 \mathrm{~g}$ & $1,25 \mathrm{~g}$ & $2,50 \mathrm{~g}$ \\
Na-CMC & $1,25 \mathrm{~g}$ & $1,25 \mathrm{~g}$ & $1,25 \mathrm{~g}$ \\
Gliserin & $2,50 \mathrm{~g}$ & $2,50 \mathrm{~g}$ & $2,50 \mathrm{~g}$ \\
Propilenglikol & $2,50 \mathrm{~g}$ & $2,50 \mathrm{~g}$ & $2,50 \mathrm{~g}$ \\
Aquadest & ad 25 & ad 25 & ad 25 \\
\hline
\end{tabular}

\section{Pembuatan luka pada tikus}

Rambut tikus dicukur bagian punggungnya dan dibersihkan dengan alkohol 70\%. Setelah itu tikus dianestesi dengan ketamin. Pola luka dibuat berbentuk lingkaran dengan diameter $2 \mathrm{~cm}$.

\section{Uji aktivitas penyembuhan luka}

Penentuan aktivitas penyembuhan luka menggunakan metode Morton. Pada hari ke-0 tikus dianestesi menggunakan ketamin $\mathrm{HCl}$ kemudian diletakkan dengan posisi telungkup di atas papan bedah. Rambut tikus dicukur bagian punggungnya dan dibersihkan menggunakan alkohol 70\%. Pola luka dibuat dengan panjang sisi- sisinya $2 \mathrm{~cm}$. Sejumlah 25 ekor tikus yang sudah dilukai punggungnya dibagi menjadi 5 kelompok sebagai berikut: kelompok kontrol negatif (basis gel), kelompok kontrol positif (bioplacenton), kelompok gel 1\%, kelompok gel 5\%, dan kelompok gel 10\%. Persentase penyembuhan luka diukur berdasarkan luas daerah luka, Pengukuran dilakukan pada semua hewan uji dimulai hari ke-0 sampai dengan hari ke-7 menggunakan jangka sorong sampai $0.1 \mathrm{~mm}$ terdekat. Perlakuan pemberian gel dilakukan setiap 2x/hari (pagi dan sore) sebanyak $100 \mathrm{mg}$. Luas dianggap berbentuk lingkaran sehingga luas luka dihitung sebagai berikut: 


$$
\mathrm{L}=1 / 4 \pi \times \mathrm{D}^{2}
$$

Sedangkan persentasi penyembuhan luka diperhitungkan dengan rumus

D1 = diameter luka sehari setelah luka dibuat.

$$
L=\frac{D 1^{2}-D 2^{2}}{D 1^{2}} \times 100 \%
$$

D2 = diameter luka pada hari pengamatan.

\section{Analisis Data}

Analisis data menggunakan program SPSS 20.0 For Windows. Dilakukan uji normalitas dengan uji kolmogorov smirnov untuk membuktikan bahwa data terdistribusi normal dan homogenitas varian menurut uji levene. Untuk melihat ada tidaknya perbedaan waktu untuk penyembuhan luka antar perlakuan dengan control menggunakan uji One Way Anova. Luka dinyatakan sembuh ditandai dengan perubahan diameter luka yang semakin mengecil atau persentase penyembuhan luka yang semakin membesar.Data disajikan dalam tabel. Hasil uji One Way Anova menunjukkan adanya perbedaan signifikan pada kelompok percobaan jika nilai $\mathrm{p}<0.05$.

\section{HASIL DAN PEMBAHASAN}

Identifikasi dan determinasi tanaman pisang dilakukan di laboratorium Biologi Farmasi Universitas Ahmad Dahlan. Berdasarkan surat keterangan Nomor 050/Lab.Bio/B/III/ 2016 dapat disimpulkan bahwa tanaman yang digunakan untuk penelitian adalah benar Musa paradisiaca L. Hasil maserasi ekstrak daun pisang dengan $1 \mathrm{~kg}$ daun pisang dan 2 liter etanol menghasilkan ekstrak kental 235 gram. Ekstrak daun pisang berbentuk sangat kental, warna hijau kehitaman, rasa pahit, dan berbau khas pisang.

Pembuatan gel ekstrak daun pisang dengan basis Na-CMC bertujuan untuk mendapatkan gel yang jernih, bersifat netral dan memiliki daya pengikat yang kuat. Pada pembuatan gel ini juga ditambahkan gliserin dan propilenglikol sebagai humektan atau penahan lembab yang berfungsi meningkatkan kelembutan dan daya sebar sediaan juga melindungi dari kemungkinan sediaan menjadi kering.

Gel yang dihasilkan memiliki bentuk setengah padat dan mempunyai bau khas daun pisang yang semakin tinggi kadar ekstrak semakin berbau aroma khas daun pisang. Untuk basis gelnya tidak berbau. Warna gel kehijauan menunjukkan adanya ekstrak daun pisang. Hal ini tampak dari perubahan warna basis gel yang awalnya bening menjadi kehijauan. Semakin tinggi kadar ekstrak maka warnanya semakin hijau.

Hasil pengukuran $\mathrm{pH}$ dengan $\mathrm{pH}$ meter diperoleh nilai $\mathrm{pH}$ untuk basis gel 6,5, gel dengan ekstrak 1\% 4,9, gel dengan ekstrak 5\% 5,2 dan gel dengan ekstrak 10\% 5,7. Basis gel dan gel ekstrak daun pisang yang dibuat memenuhi syarat sediaan topikal kulit. Nilai $\mathrm{pH}$ suatu sediaan topical harus sesuai $\mathrm{pH}$ kulit yaitu 4,5-6,5 (Tranggono dan Latifa, 2007). Nilai pH yang terlau asam dapat menyebabkan iritasi kulit dan terlalu basa menyebabkan kulit bersih. Pengujian daya sebar bertujuan untuk mengetahui kemampuan penyebaran gel. Daya sebar 5-7 cm menunjukkan konsistensi setengah padat yang sangat nyaman dalam penggunaan (Garg et al., 2002). Dari hasil pengamatan uji daya sebar diperoleh hasil daya sebar untuk basis gel 2,71 cm. gel dengan ekstrak 1\%. 2,64 cm, gel dengan ekstrak 5\%. 2,34 cm dan gel dengan ekstrak 10\% $1,86 \mathrm{~cm}$. Berdasarkan hasil tersebut dapat diketahui bahwa variasi konsentrasi basis dalam formula gel dapat mempengaruhi kemampuan daya sebar, daya sebar gel dari penelitian ini tidak terlalu besar. Sediaan gel yang mempunyai viskositas rendah menghasilkan diameter penyebaran yang lebih besar. Semakin tinggi konsentrasi basis, maka akan semakin rendah daya sebar gel karena viskositasnya meningkat dan ikatan antar polymer kuat (Tunjungsari, 2012).

Uji daya lekat dilakukan untuk mengetahui kemampuan gel melekat pada tempat aplikasinya. Daya lekat basis berhubungan dengan lamanya kontak antara basis dengan kulit, dan kenyamanan penggunaan basis. Berdasarkan hasil pengujian daya lekat, basis gel mempunyai daya lekat 1,8 detik, 
gel 1\% 1,9 detik, gel 5\% 2,2 detik dan gel 10\% 2,3 detik. Syarat untuk daya lekat pada sediaan topikal pada penelitian sebelumnya disebutkan adalah tidak kurang dari 4 detik (Ulaen et al., 2012). hal ini menunjukkan sediaan gel ekstrak daun pisang (Musa paradisiaca L.) dengan berbagai konsentrasi tidak memenuhi persyaratan daya lekat. Hal tersebut terjadi karena gel konsentrasi basis yang rendah $(0,5 \%)$ dalam formula memiliki kandungan air yang lebih banyak, viskositas lebih rendah dan waktu daya lekat lebih cepat bila dibandingkan dengan gel yang mengandung konsentrasi basis lebih tinggi karena viskositasnya juga lebih tinggi dan waktu daya lekat gel akan lebih lama, sehingga dapat disimpulkan bahwa variasi konsentrasi basis (1\%-10\%) mempengaruhi kemampuan daya lekat gel. Adanya bahan alam ekstrak dalam formula juga mempengaruhi kemampuan daya lekat gel yaitu penurunan viskositas yang menyebabkan waktu daya lekat lebih cepat (Tunjungsari, 2012).

Persentase penyembuhan luka diukur berdasarkan luas daerah luka dan diukur menggunakan jangka sorong sampai $0.1 \mathrm{~mm}$ terdekat/luka mongering secara merata.Pengukuran dilakukan pada hewan uji pada semuai replikasi dan semua kelompok perlakuan mulai hari ke-0 sampai hari ke-7. Perlakuan pemberian gel dilakukan $2 \mathrm{x}$ sehari.Pengujian aktivitas penyembuhan luka ekstrak gel daun pisang dibagi menjadi lima kelompok perlakuan yaitu kontrol negatif (basis gel), kontrol positif (bioplacenton), dan tiga kelompok dari sediaan gel ekstrak daun pisang dengan konsentrasi masingmasing $1 \%, 5 \%$ dan 10\%. Adanya aktivitas penyembuhan luka ditandai dengan semakin kecilnya ukuran diameter luka dan mengeringnya luka secara merata.

Luka tikus pada hari ke-1 setelah pemberian gel ekstrak daun pisang terlihat masih basah dan belum kering. Luka berada pada fase koagulasi yaitu setelah luka terjadi terjadi perdarahan pada daerah luka yang diikuti dengan aktifasi kaskade pembekuan darah sehingga terbentuk klot hematoma. Pada hari ke-7 luka sudah mulai mengering dan tidak basah dan luka berada pada fase proliferatif. Fase proliferatif terjadi dari hari ke 4-21 setelah trauma. Keratinosit disekitar luka mengalami perubahan fenotif. Regresi hubungan desmosomal antara keratinosit pada membran basal menyebabkan sel keratin bermigrasi kearah lateral. Keratinosit bergerak melalui interaksi dengan matriks protein ekstraselular (fibronectin,vitronectin dan kolagen tipe I). Faktor proangiogenik dilepaskan oleh makrofag, vascular endothelial growth factor (VEGF) sehingga terjadi neovaskularisasi dan pembentukan jaringan granulasi (Hunt et al., 2004). Pada fase proliferasi (4-21 hari), terjadi 4 proses, yaitu: epitelisasi, fibroplasia, angiogenesis, dan kontraksi. Epitelisasi adalah migrasi sel-sel epidermis, dari tepi luka ke arah tengah luka. Fibroplasia adalah proliferasi dari fibroblas dan produksi dari kolagen tipe 2, elastin, fibronektin, glikosaminoglikan, dan protease. Angiogenesis adalah proses pembentukan pembuluh darah baru pada luka. Kontraksi terjadi sebagai akibat dari terbentuknya kolagen, maka akan terjadi daya tarik (sentripetal) yang menarik tepi-tepi luka ke arah tengah untuk memperkecil ukuran luka (Landen et al., 2016)

Perubahan nyata terlihat pada kelompok control positif dan kelompok perlakuan gel ekstrak 5\% dan $10 \%$. Aktivitas penyembuhan luka terendah dari ekstrak gel daun pisang dengan konsentrasi $1 \%$. Hal ini diduga karena konsentrasi ekstrak yang rendah. Perbedaan diameter luka pada kelompok kontrol negatif, positif dan perlakuan mulai terlihat pada pengamatan hari ke 3 bila dibandingkan dengan diameter luka pada hari ke-1. Pada fase ini fibroblast membentuk kolagen dan jaringan ikat dan juga terjadi pembentukan kapiler baru yang dimulai saat terjadi peradangan (Harvey, 2005). Diameter awal yang menjadi dasar perhitungan persentase penyembuhan luka adalah diameter hari ke-1 karena ketidakstabilan luka hingga 24 jam setelah tikus dilukai. 
Tabel. II Rerata hasil pengukuran diameter luka

\begin{tabular}{lcccccccc}
\hline Kelompok & $\begin{array}{l}\text { Hari } \\
\text { ke-0 } \\
(\mathbf{m m})\end{array}$ & $\begin{array}{l}\text { Hari } \\
\mathbf{k e - 1} \\
(\mathbf{m m})\end{array}$ & $\begin{array}{l}\text { Hari } \\
\mathbf{k e - 2} \\
(\mathbf{m m})\end{array}$ & $\begin{array}{l}\text { Hari } \\
\mathbf{k e - 3} \\
(\mathbf{m m})\end{array}$ & $\begin{array}{l}\text { Hari } \\
\mathbf{k e - 4} \\
(\mathbf{m m})\end{array}$ & $\begin{array}{l}\text { Hari } \\
\mathbf{k e - 5} \\
(\mathbf{m m})\end{array}$ & $\begin{array}{l}\text { Hari } \\
\mathbf{k e - 6} \\
(\mathbf{m m})\end{array}$ & $\begin{array}{l}\text { Hari } \\
\mathbf{k e - 7} \\
(\mathbf{m m})\end{array}$ \\
\hline Kontrol negatif & 20,00 & 21,42 & 21,27 & 20,17 & 19,78 & 19,45 & 18,98 & 18,65 \\
Kontrol Positif & 20,00 & 21,79 & 20,69 & 19,16 & 18,12 & 15,78 & 13,89 & 12,25 \\
Gel 1\% & 20,00 & 21,33 & 20,61 & 19,91 & 18,96 & 18,60 & 18,16 & 18,65 \\
Gel 5\% & 20,00 & 21,31 & 20,72 & 19,51 & 18,84 & 17,75 & 16,81 & 15,98 \\
Gel 10\% & 20,00 & 21,71 & 20,25 & 19,10 & 17,49 & 16,31 & 15,88 & 15,48 \\
\hline
\end{tabular}

Data diameter yang telah diperoleh kemudian dihitung persen penurunan diameter luka pada tikus. Adanya penurunan luka pada kelompok perlakuan karena kandungan kimia dari daun pisang seperti flavonoid dan dan saponin yang sudah terbukti dapat mempercepat penyembuhan luka.

Tabel.III Hasil dan rereta persenatse penyembuhan luka tiap kelompok

\begin{tabular}{ccccc}
\hline Kontrol negatif & Kontrol positif & Gel 1\% & Gel 5\% & Gel 10\% \\
\hline 24,86 & 67,80 & 32,63 & 50,76 & 51,77 \\
26,60 & 64,22 & 39,01 & 37,91 & 50,26 \\
17,19 & 74,96 & 33,70 & 52,17 & 48,13 \\
27,38 & 74,26 & 27,38 & 41,42 & 48,82 \\
21,28 & 59,02 & 21,28 & 33,85 & 46,99 \\
\hline
\end{tabular}

Uji hipotesis menggunakan Analysis of Variance (Anova). Berdasarkan uji normalitas dengan uji kolmogorov dan homogenitas varian menurut uji levene diketahui data persentase penyembuhan luka terdistribusi normal dan homogen maka memenuhi syarat untuk dilakukan uji menggunakan ANOVA.

Hasil uji ANOVA menunjukkan nilai sig 0,000 lebih kecil dari nilai kritik $\alpha=0,05$ yang berarti terdapat perbedaan signifikan rata-rata presentase penyembuhan luka antar semua kelompok perlakuan yang berarti bahwa gel ekstrak daun pisang $1 \%, 5 \%$ dan $10 \%$ efektif untuk luka. Setelah uji ANOVA dilanjutkan dengan uji Post Hoc Tukey HSD untuk mengetahui perbedaan antar kelompok perlakuan.

Tabel V. Hasil uji Post Hock Tuckey HSD

\begin{tabular}{llccl}
\hline \multicolumn{2}{c}{ Perlakuan } & Sig & Hipotesis & Kesimpulan \\
\hline Kontrol Positif & Kontrol negatif &, 000 & $\mathrm{p}<0,05$ & Berbeda bermakna \\
& Gel 1\% &, 000 & $\mathrm{p}<0,05$ & Berbeda bermakna \\
& Gel 5\% &, 000 & $\mathrm{p}<0,05$ & Berbeda bermakna \\
& Gel 10\% &, 001 & $\mathrm{p}<0,05$ & Berbeda bermakna \\
Kontrol negatif & Kontrol positif &, 000 & $\mathrm{p}<0,05$ & Berbeda bermakna \\
& Gel 1\% &, 323 & $\mathrm{p}>0,05$ & Tidak berbeda bermakna \\
& Gel 5\% &, 000 & $\mathrm{p}<0,05$ & Berbeda bermakna \\
& Gel 10\% &, 000 & $\mathrm{p}<0,05$ & Berbeda bermakna \\
\hline
\end{tabular}

Hasil Post Hoc Tukey HSD pada taraf kepercayaan 95\% menunjukkan perbedaan bermakna pada kelompok kontrol negatif bila dibandingkan dengan kelompok kontrol positif dan kelompok perlakuan gel 5\% dan 10\%. Adanya perbedaan bermakna tersebut menunjukkan bahwa bioplacenton (kontrol positif), gel 5\% dan 10\% mempunyai efek penyembuhan luka. Sedangkan gel $1 \%$ tidak mempunyai efek penyembuhan luka dikarenakan konsentrasi ekstrak yang terlalu kecil. Dengan menggunakan parameter persen penyembuhan luka efektifitas gel 10\% lebih baik bila dibandingkan dengan gel ekstrak 5\%. Berdasarkan uji Post Hoc Tukey HSD menunjukkan kelompok kontrol positif bila dibandingkan dengan kelompok perlakuan gel 5\% dan 10\% menunjukkan perbedaan bermakna, 
perbedaan yang terjadi dengan melihat hasil descriptive statistic menunjukkan nilai rerata persentase penyembuhan luka kontrol positif lebih tinggi dibandingkan kelompok perlakuan. Hal ini berarti perbedaan yang dimaksudkan bahwa kontrol positif (bioplacenton) memiliki aktivitas yang lebih baik. Sedangkan kelompok gel 5\% bila dibandingkan dengan kelompok gel 10\% menunjukkan tidak ada perbedaan yang signifikan hal ini berarti kelompok gel 5\% dengan 10\% mempunyai efektifitas penyembuhan luka yang sebanding.Peningkatan konsentrasi gel tidak meningkatkan efektifitasnya karena konsentrasi 5\% adalah konsentrasi dan efek maksimal sehingga meskipun dosisnya meningkat responnya tetap sama.

Daun pisang mengandung berbagai jenis senyawa aktif fitokimia termasuk alkaloid, flavonoid, steroid, glikosida, dan saponin. Flavonoid dan saponin diduga efektif untuk luka (Pribadi, 2014). Mekanisme kerja flavonoid pada luka dengan melancarkan peredaran darah ke seluruh tubuh dan mencegah penyumbatan pada pembuluh darah (Wahyuningsih, 2006). Menurut Budi (2015) flavonoid, saponin dan tanin bersifat sebagai antioksidan, proangiogenesis dan dapat meningkatkan pasokan oksigen dan menutrisi pada kulit yang terluka.

Hasil Post Hoc Tukey HSD pada taraf kepercayaan 95\% menunjukkan perbedaan bermakna pada kelompok kontrol negatif bila dibandingkan dengan kelompok kontrol positif dan kelompok perlakuan gel $5 \%$ dan $10 \%$. Adanya perbedaan bermakna tersebut menunjukkan bahwa bioplacenton (kontrol positif), gel 5\% dan 10\% mempunyai efek penyembuhan luka. Sedangkan gel 1\% tidak mempunyai efek penyembuhan luka dikarenakan konsentrasi ekstrak yang terlalu kecil. Dengan menggunakan parameter persen penyembuhan luka efektifitas gel $10 \%$ lebih baik bila dibandingkan dengan gel ekstrak 5\%. Berdasarkan uji Post Hoc Tukey HSD menunjukkan kelompok kontrol positif bila dibandingkan dengan kelompok perlakuan gel 5\% dan $10 \%$ menunjukkan perbedaan bermakna, perbedaan yang terjadi dengan melihat hasil descriptive statistic menunjukkan nilai rerata persentase penyembuhan luka kontrol positif lebih tinggi dibandingkan kelompok perlakuan. Hal ini berarti perbedaan yang dimaksudkan bahwa kontrol positif (bioplacenton) memiliki aktivitas yang lebih baik. Sedangkan kelompok gel 5\% bila dibandingkan dengan kelompok gel 10\% menunjukkan tidak ada perbedaan yang signifikan hal ini berarti kelompok gel 5\% dengan 10\% mempunyai efektifitas penyembuhan luka yang sebanding.Peningkatan konsentrasi gel tidak meningkatkan efektifitasnya karena konsentrasi 5\% adalah konsentrasi dan efek maksimal sehingga meskipun dosisnya meningkat responnya tetap sama.

Daun pisang mengandung berbagai jenis senyawa aktif fitokimia termasuk alkaloid, flavonoid, steroid, glikosida, dan saponin. Flavonoid dan saponin diduga efektif untuk luka (Pribadi, 2014). Mekanisme kerja flavonoid pada luka dengan melancarkan peredaran darah ke seluruh tubuh dan mencegah penyumbatan pada pembuluh darah (Wahyuningsih, 2006). Menurut Budi (2015) flavonoid, saponin dan tanin bersifat sebagai antioksidan, proangiogenesis dan dapat meningkatkan pasokan oksigen dan menutrisi pada kulit yang terluka.

\section{KESIMPULAN}

Gel ekstrak daun pisang efektif untuk penyembuhan luka pada tikus jantan galur wistar. Gel ekstrak daun pisang dengan konsentrasi 5\% dan 10\% mampu mempercepat penyembuhan luka. Dua kelompok ini berbeda siginifikan dengan kelompok kontrol negatif. Gel ekstrak konsentrasi 5\% dan $10 \%$ mempunyai efektifitas yang sebanding untuk penyembuhan luka.

\section{UCAPAN TERIMAKASIH}

Penelitian ini terselenggara atas bantuan Hibah DIKTI melalui skema penelitian eksakta Program Kreativitas Mahasiswa (PKM) Tahun Anggaran 2015.

\section{DAFTAR PUSTAKA}

Advanced Medical Technology Association, 2006, Advanced Wound Management, Healing and Restoring lives.

Ansel, H.C., 2005, Pengantar Bentuk Sediaan Farmasi, Edisi IV, diterjemahkan oleh Ibrahim, F.,390393, Universitas Indonesia Press, Jakarta. 
Budi HS, Kriswandini IL, Iswara AD. 2015,Antioxidant activity test on ambonese banana stem sap (Musa parasidiaca var. sapientum), Dental Journal, 48 (4), 188-92.

Garg, A., D. Aggarwal, S. Garg, and A. K. Sigla. 2002. Spreading of Semisolid Formulation: An Update. Pharmaceutical Technology. September: 84-102.

Harvey, C, 2005, Wound Healing. Orthopaedic Nursing. 24 (2), 143-159.

Hunt TK, Ellison EC, Sen CK, 2004, Oxygen: at the foundation of wound healing-introduction. World J Surg, 28 (3), 291-3.

Karuppiah, P., \& Mustaffa, M. (2013). Antibacterial and Antioxidant Activities of Musa Sp. Leaf Extracts Against Multidrug Resistant Clinical Pathogens Causing Nosocomial Infection. Asian Pacific Journal of Tropical Biomedicine, 3(9), 737-742.

Landén NX, Li D, Ståhle M, 2016, Transition from inflammation to proliferation: A critical step during wound healing, Cell Mol Life Sci CMLS, 73 (20), 3861-85.

Ningsih Ayu Putrid, Nurmiati, Agustien, 2013, Uji aktivitas antibakteri ekstrak kental tanaman pisang kapok kuning (Musa paradisiacal Linn) terhadap Stapylococcus aureus dan Escherichia coli, Jurnal Biologi Universitas Andalas, 2 (3), 207-213.

Pribadi, P., Latifah, E., \& Rohmayanti, R, 2014, Pemanfaatan perasan buah kepel (Stelechocarpus burahol (Blume) Hook \& Thomson) sebagai antiseptik luka, Pharmaciana, 4 (2), 177-183.

Sahaa et al, 2013, Medicinal activities of the leaves of Musa sapientum var sylvesteris in vitra, Asian Pasific Journal of tropical Biomedicine, 3 (6), 476-482.

Swathi D, Jyothi B, Sravant a, 2011, Review : Pharmacognostic studies and Pharmacological actions of Musa Paradisiaca, International Journal of Innovative Pharmaceutical Research, 2(2)122125.

Tranggono, RI, Latifah, F, 2007, Buku Pegangan Ilmu Pengetahuan Kosmetika. PT. Gramedia: Jakarta.

Tunjungsari, D., 2012, Formulasi Sediaan Gel ekstrak etanolik buah mahkota dewa (Phaleria macrocarpa (Scheff) Boerl.) dengan Basis Carbomer, Skripsi, Fakultas Farmasi Universitas Muhammadiyah Surakarta.

Ulaen, S. P. J., Banne, Y., dan Suatan, R. A., 2012, Pembuatan salep anti jerawat dari ekstrak rimpang temulawak (Curcuma Xanthorrhiza Roxb.), Jurnal Ilmiah Farmasi, 3 (2), 47-48.

Wahyuningsih, S. Soemardji, A.A. \& Febiyanti, D, 2006, Efek gel lidah buaya (Aloe barbadensis Mill) terhadap penyembuhan luka bakar eksperimen pada tikus wistar betina, Prosiding Seminar Nasional Tumbuhan Obat Indonesia XXIX, 73-81.

Weremfo, Pappoe N,M, Adinortey, 2011, Wound healing potential of Musa Paradisiaca L (musaceae) stem juice extract formulated into an ointment, Research J Topical and Cosmetic Sci, 2(2): 7072 . 